\title{
Beyond Human
}




\title{
BUCKNELL STUDIES IN LATIN AMERICAN LITERATURE AND THEORY
}

\author{
Series editor: Aníbal González, Yale University
}

Dealing with far-reaching questions of history and modernity, language and selfhood, and power and ethics, Latin American literature sheds light on the many-faceted nature of Latin American life, as well as on the human condition as a whole. This highly successful series has published some of the best recent criticism on Latin American literature. Acknowledging the historical links and cultural affinities between Latin American and Iberian literatures, the series productively combines scholarship with theory and welcomes consideration of Spanish and Portuguese texts and topics, while also providing a space of convergence for scholars working in Romance studies, comparative literature, cultural studies, and literary theory.

\section{Selected Titles in the Series}

Rebecca E. Biron, Elena Garro and Mexico's Modern Dreams

Persephone Brahman, From Amazons to Zombies: Monsters in Latin America Jason Cortés, Macho Ethics: Masculinity and Self-Representation in Latino-Caribbean Narrative

Tara Daly, Beyond Human: Vital Materialisms in the Andean Avant-Gardes

Earl E. Fitz, Machado de Assis and Female Characterization: The Novels

Thomas S. Harrington, Public Intellectuals and Nation Building in the Iberian Peninsula, Igoo-Ig25: The Alchemy of Identity

David Kelman, Counterfeit Politics: Secret Plots and Conspiracy Narratives in the Americas

Brendan Lanctot, Beyond Civilization and Barbarism: Culture and Politics in Postrevolutionary Argentina

Adriana Méndez Rodenas, Transatlantic Travels in Nineteenth-Century Latin America: European Women Pilgrims

Andrew R. Reynolds, The Spanish American Crónica Modernista, Temporality, and Material Culture

Elisa Sampson Vera Tudela, Ricardo Palma's Tradiciones: Illuminating Gender and Nation

Mary Beth Tierney-Tello, Mining Memory: Reimagining Self and Nation through Narratives of Childhood in Peru 


\section{Beyond Human}

\section{Vital Materialisms in the Andean Avant-Gardes}

TARA DALY

Bucknell|BUCKNELL 
Library of Congress Cataloging-in-Publication Data

Names: Daly, Tara, author.

Title: Beyond human : vital materialisms in the Andean avant-gardes / Tara Daly.

Description: Lewisburg : Bucknell University Press, [2019] | Series: Bucknell Studies in

Latin American Literature and Theory Includes bibliographical references and index.

Identifiers: LCCN 2018029490| ISBN 9781684480685 (cloth)| ISBN 9781684480678

(paperback)

Subjects: LCSH: Literature, Experimental-Latin America-History and criticism. |

Avant-garde (Aesthetics) - Latin America. | Materialism in literature.

Classification: LCC PQ7082.E97 D35 2019 | DDC 860.9/1 I-dc23

LC record available at https://lccn.loc.gov/2018029490

A British Cataloging-in-Publication record for this book is available from the British Library.

Copyright ( 2019 by Tara Daly

All rights reserved

No part of this book may be reproduced or utilized in any form or by any means, electronic or mechanical, or by any information storage and retrieval system, without written permission from the publisher. Please contact Bucknell University Press, Hildreth-Mirza Hall, Bucknell University, Lewisburg, PA $17837-2005$. The only exception to this prohibition is "fair use" as defined by U.S. copyright law.

$\otimes$ The paper used in this publication meets the requirements of the American National Standard for Information Sciences-Permanence of Paper for Printed Library Materials, ANSI Z 39.48-1992.

www.bucknell.edu/UniversityPress

Distributed worldwide by Rutgers University Press

Manufactured in the United States of America 
To Laura and Jasper 
